3. Лобашев М. Е. Генетика с основами селекции: Учеб. Пособие для студентов пед. ин-тов по биол. Спец. «Просвещение», 1979. 67 с.

4. Лобан Н. А. Геномная селекция в свиноводстве: РУП «Научнопрактический центр Национальной академии наук Беларуси по животноводству», 2013. 165, 145, 146 с.

DOI https://doi.org/10.30525/978-9934-26-047-6-9

\title{
ЖУКИ-СТАФІЛІНІДИ (СОLЕОРТЕRА: STAPНYLINIDAE: ALEOCHARINAE) РОДУ ZYRAS В КОЛЕКЦІЇ ІНСТИТУТУ ЗООЛОГІЇ ІМ. І. І. ШМАЛЬГАУЗЕНА НАН УКРАЇНИ
}

\author{
Глотов С. В.
}

молодший науковий співробітник відділу

музейного документування біоресурсів

Державний природознавчий музей Національної академії наук Украӥни м. Львів, Украӥна

\section{Гуштан Г. Г.}

кандидат біологічних наук,

молодший науковий співробітник відділу біосистематики та еволюиї Державний природознавчий музей Національної академії наук України м. Львів, Україна

\section{Гуштан К. В.}

кандидат біологічних наук,

молодиий науковий співробітник відділу музейного

документування біоресурсів

Державний природознавчий музей Національної академії наук України

м. Львів, Україна, викладач

Екологічний коледж

Львівського національного аграрного університету м. Львів, Україна

Рід Zyras Stephens, 1835 входить до складу підтриби Myrmedoniina, триби Lomechusini, підродини Aleocharinae. В світовій фауні відомо 
806 видів [4, с. 1-72], в фауні Палеарктики 97 видів [5, с. 671]. В Україні рід представлений трьома видами.

Діагноз. Розмір тіла представників роду - 4-6 мм. Забарвлення тіла та окремих частин може бути яскравих контрастних кольорів; вусики, щелепні щупики та ноги коричневі або світло-коричневі. Усе тіло опукле та трохи видовжене; гладеньке та блискуче, по всій поверхні рідко вкрито короткими щетинками. Голова помірно велика, поперечна та опукла; очі дрібні та слабо опуклі; вусики стрункі та помірно видовжені, поступово розширюються, 1-3 членики сильно видовжені, 4 членик квадратний або слабо поперечний, 5-10 членики поперечні. Надкрила короткі та опуклі, трохи ширші та довші за передньоспинку. Черевце опукле і трохи розширене посередині; по всій поверхні помірно густо дрібно пунктирне, до вершини поступово звужується; у самців задній край VIII тергіта пилчастий або з короткими виростами, у напрямку заднього краю помітно звужується, у самиць задній край VIII тергіта рівний або в середині неглибоко втиснений, у напрямку заднього краю помітно звужується.

Біономія. Личинки та імаго $є$ неспеціалізованими хижаками, які живляться різноманітними безхребетними, виступаючи в ролі природних регуляторів їхньої чисельності. Де активно населяють підстилку, рослинні рештки, а також зустрічаються на вологих місцях, по берегам річок та водойм, крім того окремі представники роду успішно співіснують з мурахами.

В результаті вивчення колекційного матеріалу з наукових фондових колекцій Інституту зоології ім. І. І.Шмальгаузена НАН України, було опрацьовано та визначено 27 взірців, які належать до 3 видів (Zyras collaris (Paykull, 1800), Zyras fulgidus (Gravenhorst, 1806), Zyras haworthi (Stephens, 1832)). Переважна більшість екземплярів (за даними етикеток) була зібрана на території України (у АР Крим, Донецькій, Київській, Херсонській, Черкаській областях), а також на теренах Азейбарджану, Вірменії, Росії та Угорщини.

Камеральна обробка та визначення матеріалу здійснювалася за загальновідомими методами та методиками ентомологічних досліджень, визначення жуків проводилося 3 використанням бінокулярної лупи МБС-10. У разі необхідності мандибули, генітальні апарати та інші частини тіла жуків відпрепаровувалися та фіксувалися за допомогою тонких препарувальних голок [1, с. 197-199]. Іноді матеріал просвітлювався кип'ятінням або витримкою у $10 \%$ розчині $\mathrm{NaOH}$. Після цього органи поміщалися у фіксуючу рідину для тривалого зберігання, в якості фіксатора застосовувалися канадський 
бальзам або евпараль. Всі наявні в колекції взірці було перевизначено за сучасними методиками діагностики видів за допомогою визначника алеохарін Центральної Європи [2], та визначника видів родів Pella та Zyras Палеарктики [3].

\section{Zyras (Zyras) collaris (Paykull, 1800)}

Матеріал. Україна. Київська обл.: Київ, Голосіївський р-н, Голосіївський ліс, 50.384731 N, 30.515105 Е, 13.10.1957, 1 екз.; там само, текст написано нерозбірливо, 12-25.03.1920, 1 екз., В. Лучник [V. Lutshnik]; без зазначення дати та місця збору, 05.08.1932, 2 екз. Росія: Челябінська обл.: Ільменський державний заповідник імені В. І. Леніна, $55.0055 \mathrm{~N}, 60.0932$ Е, в мулистому грунті, 26.06.1985, 1 екз., А. Петренко; Приморський край: Кедрова падь, 17.08.1985, 1 екз., 3. Берест. Угорщина: без зазначення локалітету та дати збору, 1 екз.

Біономія. Жуки зустрічаються в лісовій підстилці, в мохах, в рештках рослинного походження, на вологих місцях, по берегах річок та водойм.

Поширення. Свропа, Кавказ, Північна Африка, Іран [5].

Zyras (Zyras) fulgidus (Gravenhorst, 1806)

Матеріал. Україна: Донецька обл.: Новоазовський р-н, заповідник «Хомутовський Степ», 47.288518 N, 38.186491 Е, 16.10.1974, 1 екз., В. Ермоленко; там само, 7.11.1976, 1 екз., А. Котенко; Херсонська обл.: Чаплинський район, заповідник «Асканія Нова», 46.462665, 33.986350, цілинний степ, 28.05.1974, 1 екз., В. Ермоленко. Азербайджан: Нахичеванская АР: г. Билав, $39.044200 \mathrm{~N}, 45.943100$ Е, в наносах, 16.05.1976, 2 екз., А. Петренко; там само, 21.09.1977, 2 екз., А. Петренко.

Біономія. Жуки зустрічаються в лісовій підстилці та в рештках рослинного походження, на вологих місцях, по берегах річок та водойм.

Поширення. Центральна та південна Європа, Кавказ, Іран [5].

Zyras (Zyras) haworthi (Stephens, 1832)

Матеріал. Україна. АР Крим: Ангарський перевал, 44.756639 N, 34.343282 Е, ліс, на білу тканину, 02.07.1979, 1 екз., А. Лелей; Закарпатська обл.: Тячівський р-н, с. Велика Уголька, $48.215972 \mathrm{~N}$, 23.659422 Е, 15.06.2011, 2 екз., В. Чумак. Київська обл.: м. Київ, Голосіївський ліс, 50.384731 N, 30.515105 Е, в підстилці, 21.05.1958, 1 екз.; Черкаська обл.: Канівський р-н, Канівський природний заповідник, 49.722535 N, 31.5269183 E, 05.08.1984, 2 екз., О. Павленко О.; там само, 05.06.1984, 2 екз., А. Петренко; Львівська обл.: м. Львів, 1 екз., Лідоцькі [Dr. Ligocky]. Росія. Ставропольський край: 
м. Ставрополь, 45.044562 N, 41.969330 Е, 03.06.16, 1 екз., В. Лучник [V. Lutshnik]. Вірменія. Арарат обл.: Хосровский заповідник, 40.037100 N, 44.917098 E, 05.08.1984, 2 екз., Павленко О. М. Кавказ, без зазначення локалітету, 04.07.1978, 1 екз., П. Васильєв.

Біономія. Жуки мешкають в лісах та штучних лісонасадженнях у лісовій підстилці та у рештках рослинного походження разом 3 мурахами родів Formica та Lasius.

Поширення. Свропа, Північна Африка [5].

Робота виконана в рамках наукової теми: "Оцінка біотичного різноманіття модельних груп членистоногих Українських Карпат 3 використанням сучасних інформаційних технологій".

\section{Література:}

1. Крыжановский О. Л., Емец В. М. К методике препаровки гениталий у жуков. Энтомологическое обозрение. 51 (1). 1972. C. $197-199$.

2. Lohse G. A. Family Staphylinidae. II // In: Freude H., Harde K. W., Lohse G. A. Die Kafer Mitteleuropas. Krefeld, Goecke et Evers Verlag, 5. 1974. 1-381.

3. Maruyama M. Revision of the Palearctic species of the myrmecophilous genus Pella (Coleoptera, Staphylinidae, Aleocharinae). National Science Museum Monographs. 32: I-IV. 2006. 1-207.

4. Newton A. F., Chacon C. G., Chandler D. S. Checklist of the Staphylinidae (Coleoptera) of Colombia. Biota Colombiana. 6 (1). 2005. 1-72.

5. Schülke M., Smetana A. Staphylinidae Latreille, 1802. pp. 304-1134 In: Löbl, I., Löbl, D. Catalogue of Palaearctic Coleoptera vols. 1 \& 2, Hydrophiloidea-Staphylinoidea, revised and updated edition. Brill, Leiden \& Boston, I-XXV. 2015. 1-1702. DOI: 10.1163/9789004296855. 